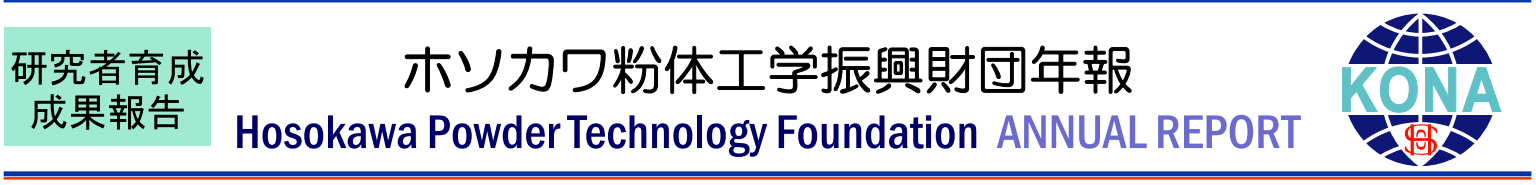

\title{
14504
}

\section{マイクロ界面拡散を利用した粒子複合化プロセスの開発 \\ Development of a Particle Composite Process Using Micro Interface Diffusion}

\author{
援助対象者 Scholarship Student: 出未 祐人 Yuto DEKI \\ 同志社大学大学院理工学研究科 博士課程後期 1 年 \\ E-mail: eup1701@mail4.doshisha.ac.jp \\ 研究指導者 Academic Leader：白川 善幸 Yoshiyuki SHIRAKAWA \\ 教授, Professor \\ E-mail: yshiraka@mail.doshisha.ac.jp
}

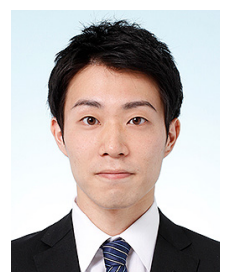

出未祐人

Graduate school of Science and Engineering, Doshisha University, PhD Student (D1)

\section{成 果 の 概 要}

緒言

異種物質を接合し，界面構造を制御すること で新機能を発現させる複合化技術は, 新規機能 性材料の創製手法として注目されている。一般 的な複合化は核となるコア粒子や多孔質粒子を 添加し, その表面や内部に異種物質を析出させ ることで達成される。しかし，添加する粒子の 調製，修飾，複合粒子の作製といった多段階プ ロセスが必要となり, 生産コストの観点から好 ましくない。また，表面被覆型や内部分散型と いった複合形態は材料の物性に直接に関与する ためその形態制御は必須である。つまり，現在 の複合粒子作製プロセスにおいて，単一プロセ ス化と複合形態制御を両立させることは重要な 技術課題である。

そこで, 我々は液滴界面というマイクロ界面 に着目した。複数の物質を溶解させた液滴を有 機溶媒中に形成した場合を考えると, 拡散の進 行とともに液滴界面上に拀いて析出速度の速い
物質から順次結晶を析出していくことが予想で きる。つまり，液滴という限定空間内で結晶化 速度の差を利用して複合化を達成することがで き，その差の大きさにより複合形態の制御も可 能であると考えられる。本研究では, 水溶液を 微粒化し有機溶媒中で球状界面を形成する噴霧 晶析法により 2 種類の溶質を含む溶液から粒子 を作製し, 粒子形態抢よび複合形態の制御につ いて検討を行った。さらに, 各溶質に対する水 の分配量から結晶化速度に差が生じる理由につ いて考察した。

\section{実験方法}

本研究では 2 種類の物質を溶解させた溶液を 使用する，最初に，塩化ナトリウム水溶液を調 製し，濃度は飽和濃度 $(5.35 \mathrm{~mol} / \mathrm{L})$ とした。 この溶液に各種アミノ酸を添加・混合すること で溶液を調製した。アミノ酸としては，グリシ ン，システインを選択した。溶液はそれぞれの アミノ酸を添加後, 1 日擋拌, 静置させること で調製した。 
霧化装置はフローター（STO-4-M II 型, 日本 フローセル株式会社製)，ローラーポンプ(古 江サイエンス株式会社, RP-NB)，2 流体ノズ ル $(\mathrm{PN} 3005$, 藤崎電機株式会社製), エアーコ ンプレッサー（SRL-DMA5/6，株式会社日立産 機システム製）から構成される。調製した溶液 をローラーポンプによってノズルに送液し, $200 \mathrm{~mL}$ の有機溶媒上部から 10 秒間噴霧した。 噴霧終了後, 有機溶媒を 60 秒間静置させ, 生 成粒子は減圧濾過により回収した。有機溶媒と しては1-ブタノールを選択した。

\section{実験結果および考察}

塩化ナトリウム/グリシン溶液を用いて作製 した粒子の SEM 画像および元素分析結果を Fig. 1 に示す. 作製した球状粒子は約 10 〜 $20 \mu \mathrm{m}$ であった。液滴径は 5〜 $15 \mu \mathrm{m}$ であり, 作製した球状粒子の粒子径と非常に近いことか ら液滴界面で粒子が生成していることが分か る。また, 球状粒子は微細なグリシン結晶と塩 化ナトリウム結晶で構成されている分散型の複 合粒子であることが分かった，次に，塩化ナト リウムノシステイン溶液を用いて作製した粒子 のSEM 画像抒よび元素分析結果を Fig. 2 に示 す。グリシンを用いた場合に得られた球状粒子 は微細な結晶が凝集した構造をとるのに対し, システインを用いた場合に得られた球状粒子は

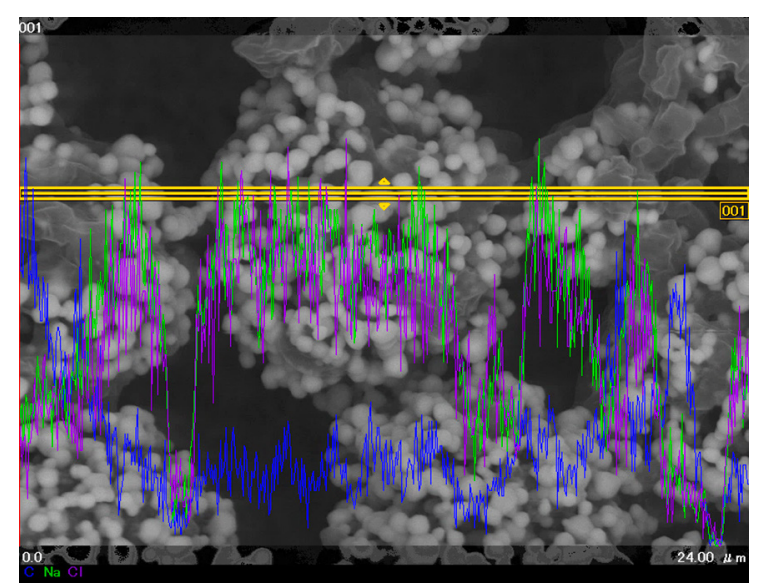

Fig. 1 Line element analysis of $\mathrm{NaCl}$-Glycine composite particle (green : $\mathrm{Na}$, purple : $\mathrm{Cl}$, blue : O)
塩化ナトリウムの中空粒子内にシステインが内 包された被覆型の構造をとっており, 粒子形態 については異なる結果を示した。これらの結果 から, 分散型, 被覆型といった複合形態は結晶 化速度の差の大小により決まると考えられる。 各溶質の結晶化速度がほぼ等しいまたはその差 が小さい場合は液滴界面で 2 種類の溶質の結晶 化が生じ, 内部分散型の構造が形成され, 各溶 質の結晶化速度が大きく異なる場合では結晶化 速度の速い物質から順次結晶化していき, 被覆 型の構造を形成していく（Fig. 3). また，この ことから溶質濃度バランスによる複合形態の制 御が示唆された。

次に, 結晶化速度に差が生じる原因について 検討した。これは水が有機溶媒, 溶質に分配す る比率が溶質種によって異なることが原因の一 つだと考えられる，そこで，水の分配に対する
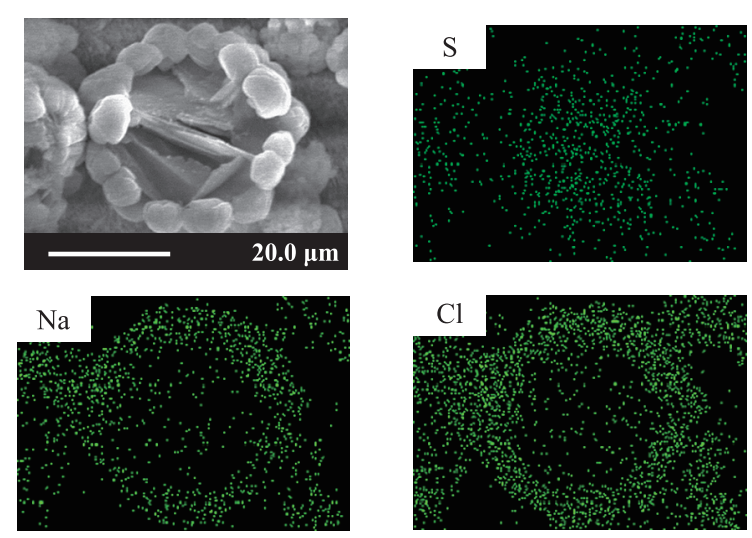

Fig. 2 Mapping images of NaCl- Cysteine composite particle

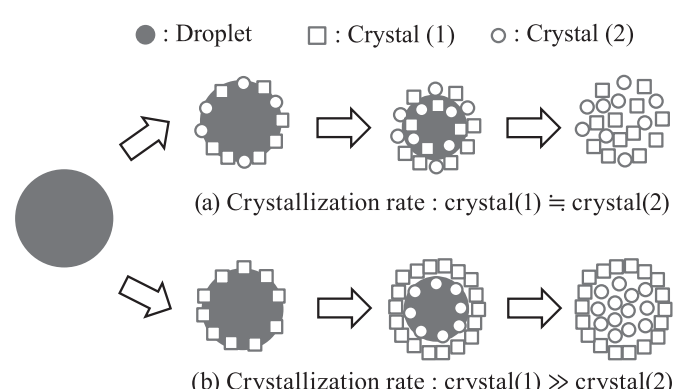

Fig. 3 Schematic illustration of the composite particle generation 


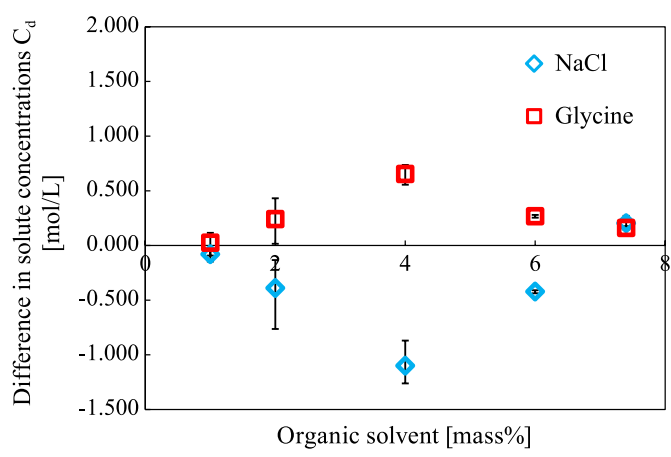

Fig. 4 Deviation of solute concentration between theoretical values and observed values

溶質の影響を検討した，各溶質の水の分配量を 示すグラフを Fig. 4 に示す. グリシンは正の值 をとり, 塩化ナトリウムは負の值をとっている. ここで，正の值である場合は水が多く分配され たことを示し，逆に負の值である場合は水の分 配が少ないことを示している。つまり，グリシ ンは多くの水分子に囲まれた状態で存在し, 塩 化ナトリウムは少量の水分子しか周囲にいない 状態で存在していることになる，流入してくる

\section{外部 発表成果}

\section{論文発表}

1. K. Gonda, K. Kadota, Y. Deki, Y. Tozuka, A. Shimosaka, Y. Shirakawa, J. Hidaka, "Fabrication of composite particles by liquidliquid interfacial crystallization using an ultrasonic spray nozzle" Powder Technol. 269 (2015) 401-408

2. Y. Deki, K. Kadota, A. Shimosaka, Y. Shirakawa, "Effect of Habit Modifier and Crystallization Speed on Composite Morphology in Atomizing Crystallization" Powder Technol. 53 (2016) 149-156

\section{口頭・ポスター発表}

1. 白川善幸, 服部祐也, 出未祐人, 下坂厚子, “マイクロ流路内における析出速度差を利用 した粒子複合化技術の開発”, 日本海水学会 第 66 年会, 神奈川, 2015 年 6 月
1-ブタノールは水に溶解する過程で界面上の溶 質の水分子を奪っていくと考えられるため, 水 の分配が少ない塩化ナトリウムは少量の1-ブ 夕ノールで大きな溶解度変化を起こし, 水の分 配が多いグリシンでは多量の1-ブタノールで しか溶解度変化を起こさなかったのだと考えら れる。 以上から, 塩化ナトリウムとグリシンの 結晶化速度に差が生じるのは水の分配比率が異 なることが原因の一つであることを明らかに した。

\section{まとめ}

液一液界面晶析の原理を応用した噴霧晶析法 を用いて 2 種類の溶質を含む溶液から粒子を作 製した結果，単一プロセスで複合粒子を作製す ることができた。 また，濃度バランスにより形 態制御が可能であることが示唆された。今後, 結晶化速度については詳細な検討のためにシ ミュレーションを用いた解析を行っていく予定 である。

2. Y. Deki, A. Shimosaka, Y. Shirakawa, "Relationship between particle morphology and mutual diffusion in liquid-liquid interfacial crystallization", International Powder and Nanotechnology Forum, Frankfurt, Germany, June 15-19, 2015

3. Y. Deki, A. Shimosaka, Y. Shirakawa, "Effect of habit modifier addition and atomization conditions on particle morphology", The 5th Int'l Conf. on the Characterization and Control of Interfaces for High Quality Advanced Materials and the 51st Summer Symposium, Kurashiki, Japan, July 7-10, 2015

4. Y. Deki, A. Shimosaka, Y. Shirakawa, "Study on solvent diffusion behavior of the interface and the particle precipitation mechanism in liquidliquid interfacial crystallization", The 6th Asian Particle Technology Symposium, Seoul, Korea, September 15-18, 2015

5. 出未祐人, 下坂厚子, 白川善幸, “複雑操作 は不要! 単一プロセスで複合化を!”APPIE 産学官連携フェア 2015, 大阪, 2015 年 10 月 